\title{
Work-Life Balance: Reality Check for the Working Women of Bangladesh
}

\author{
Mayesha Tasnim, Muhammed Zakir Hossain, Fabiha Enam \\ Department of Business Studies, State University of Bangladesh, Dhaka, Bangladesh \\ Email: mayesha.tasnim2000@gmail.com
}

How to cite this paper: Tasnim, M., Hossain, M.Z. and Enam, F. (2017) Work-Life Balance: Reality Check for the Working Women of Bangladesh. Journal of Human Resource and Sustainability Studies, 5, 7586.

https://doi.org/10.4236/jhrss.2017.51008

Received: December 29, 2016

Accepted: March 18, 2017

Published: March 21, 2017

Copyright $\odot 2017$ by authors and Scientific Research Publishing Inc. This work is licensed under the Creative Commons Attribution International License (CC BY 4.0).

http://creativecommons.org/licenses/by/4.0/

\begin{abstract}
In today's world, the concept "work-life balance" is considered to be one of the major issues that play a vital role in organizational success. However, work-life balance is seen differently in different society. This paper aims to find out the reasons, which create work-life imbalance. Since in perspective of Bangladesh, a female employee faces more difficulties to balance between work and life than a male employee, this study focuses on women working in different sectors. This study has been conducted based on primary research where a sample of 40 female employees from different organizations is selected. Questionnaire and interviews were taken to reveal the reasons that lead to the reason on an imbalance work-life. The study shows that the reasons for which female employees are facing trouble to maintain a work-life balance are mostly because of: long working hours, job rigidity, work overload, responsibilities related to child care, discrimination \& biasness at work place, lack of supervisory support, dominant managerial style and scarce family support. The finding of the study focuses on formulating a structured guideline for the organizations so that the above mentioned reasons can be omitted and female employees can balance their professional and personal life and live in harmony.
\end{abstract}

\section{Keywords}

Management, Human Resource Management, Working Women

\section{Introduction}

In today's competitive world, the issue of work-life balance has grabbed the attention of researchers and academics because of its effect on professional as well as personal life. Evident show that while a balanced work-life combination creates harmony in both professional and personal life, imbalance between work and life can create negative impact on an employee's personal life which leads to 
job dissatisfaction that damages organization's productivity and reputation.

In Bangladesh, women have been participating and contributing remarkably in our economy. Despite of it, working women experience various obstacles in their personal as well as professional life. Women are struggling to balance between work-life which ultimately hampering their social life. While trying to balance work-life, women feel the pressure not only from their work place but also from their family. Since women need to play different roles in society, it is particularly harder for women to keep balance between work-life.

This paper aims to find out the causes that create imbalance in work-life of working women in Bangladesh. Consequences and probable solutions have been provided as well since it is absolutely necessary to find out a desirable way to eliminate the problems that hampers work-life balance of working women in Bangladesh. Considering all aspects, an attempt has been made to address the following questions: 1) Causes that create imbalance in work-life of working women. 2) Consequences of the causes. 3) Probable solutions for maintaining balance between work-life of working women in Bangladesh.

\section{Literature Review}

Work-life balance has become a burning issue in today's modern world. Numerous researches have been done regarding this issue. Almost in every research, researchers tried to find out the causes that create imbalance between professional and personal life. Not only that but also researchers focused on the consequences on the aspect of imbalance work-life and provided solution to balance between work-life.

While the issue of balancing between work-life has come into the lime light, the reality is, employees are constantly juggling between to keep a balance between their professional and personal life [1]. According to Tomazevic, Kozjek and Stare (2014) the meaning of work-life balance is to effectively combining professional life with personal obligations and creates a harmony between these two aspects [2]. It can be defined as the absence of conflict between professional and personal life [1]. According to Amstad et al. (2011) work interfering with family is more associated with work related outcomes than family related outcomes [3]. While work-life balance has a positive consequence, imbalance in work-life has numerous negative consequence for both employees and employers [2].

According to Amstad et al. (2011) a stressful environment can create imbalance in work-life. Another reason of an imbalance work-life is the lack of support of the managers [3]. If manager does not support their sub ordinates most likely employee's work-life harmony will be affected [2]. Long working hour is another reason for creating imbalance between work and life [3]. Tomazevic, Kozjek and Stare, (2014) has discussed both positive and negative consequences as a result of both work-life balance and work-life imbalance. If there is balance in work-life, employees get motivation and job satisfaction increases while imbalance create dissatisfaction among employees. The feeling of stress and over- 
work found if there is imbalance between work-life [2]. As a result of work family conflict employees experience stress related outcomes such as depression, burn out, family related stress, general psychological strains etc. Not only this but also there is an invert relation exists between work-family conflict and job satisfaction [4]. According to Hutcheson (2012) one may experience depression or become overwhelmed as a result of imbalance in work-life [5].

Researchers have provided different kinds of solutions in order to eradicate the conflict between work-life. These solutions provide a guideline for maintaining work-life balance. According to Beutell and College (2010) supervisory support is important in order to maintain work-life balance [6]. A supportive management is required to minimize the work-life conflict. A well-defined policy is mandatory to maintain harmony between work and life [7]. Hill et al. (2001) says flexibility in timing and location of work is vital for work-life balance [8]. Keeping the work environment attractive and flexible is the key success of maintaining work-life balance in the organization [5]. Furthermore human resource department should promote policies, which incorporates corporate social responsibility, employee well-being and work-life balance [1].

\section{Methodology}

Primary data have been used for this study. For this study, the sample size consists of 40 working women in different sectors, age in between of 24 to 37 years. Purposive sampling method has been used in order select respondents for the study. Respondents are working in different sectors of Bangladesh such as: Education, IT, Software, Banking, Pharmaceuticals, Digital advertising agency, Local and International NGO and in Service Oriented company. Both questionnaire and interview methods have been used for conducting this survey. Since both interview and questionnaire have been written in English language, clerical staffs have been deducted from this study. The respondents consist of married, unmarried, and married with children. Among all the respondents, $57.5 \%$ were married, $42.5 \%$ were unmarried, $40 \%$ of married working women have children and $55 \%$ of working women do not have any children. 8 working women have been interviewed for this study. Depth interview method has been used to find out the causes, consequences, and probable solution to overcome this issue. Relevant books, articles, journals were also reviewed to make this study more informative and acceptable to all. Descriptive statistics have been used to analyze the data.

The inclusion criteria of selecting working women was that everyone needs to have minimum 6 months of job experience and they need to serve in private organizations. Working women having less than 6 months of job experience and working in government organizations were excluded from the study.

Respondents were asked 22 questions. The questionnaire tried to find out the following things:

- Which kind of working women find difficulties to balance between work-life: married or unmarried?

- How much time do they need to spend at office and whether they are satis- 
fied with the office timing?

- Do they get enough support from colleagues and family?

- What is the role of the organization to mitigate this imbalance?

- What are the consequences of over load of work at office?

- Are they facing any psychological break down due to imbalance between work-life?

\section{Findings \& Analysis}

The study indicates that women face problems to maintain balance between work-life mainly because of professional challenges they face every day. These challenges include long working hours, lack of supervisory support, work overload, absence of strong policies. As per this study, lack of family support is an issue but it is not as extensive as professional challenges. Surveys and depth interviews of this study highlighted the fact that working women of today's generation faces more professional challenges than family obstacles. The findings and analysis is represented through graphs and figures which indicates the current scenario. Figure 1 represents marital status of the sample of the study. Figure 2 and Figure 3 shows status of children and working hours of working mothers. Figure 4 shows satisfaction regarding working hour. Figure 5 and Figure 6 highlights status of work overload and family time. Figures 7-9 represents support from supervisor, peers and family. Lastly Figure 10 shows organization's initiative to balance work-life.

\section{Marital Status (40 reaponses)}

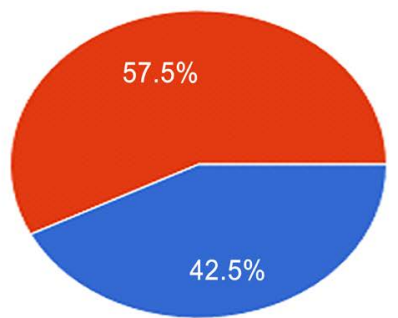

Unmarried

Married

Figure 1. Marital status of the samples for this study.

Do you have children? (if married) (40 reaponses)

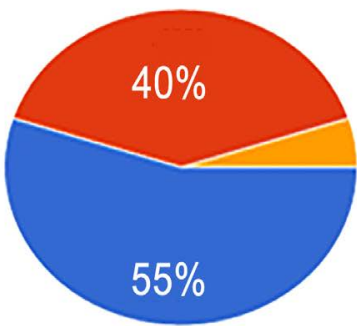

No

- Yes

Not applicable

Figure 2. Status of children. 
How many hours in a day do you normally work?

40 reaponses)

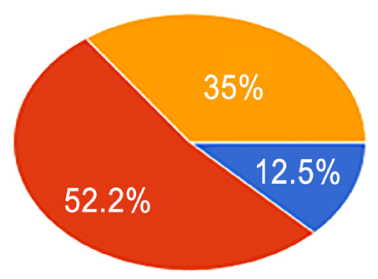

7-8 hours

8-9 hours

9-10 hours

- More than 10 hours

$52.2 \%$

Figure 3. Status of working hours.

Are you satisfied with the working hours of the organization?

(40 reaponses)

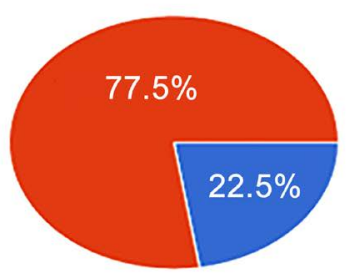

Figure 4. Satisfaction regarding working hour.

Do you generally feel that you are overloaded with work? (40 reaponses)
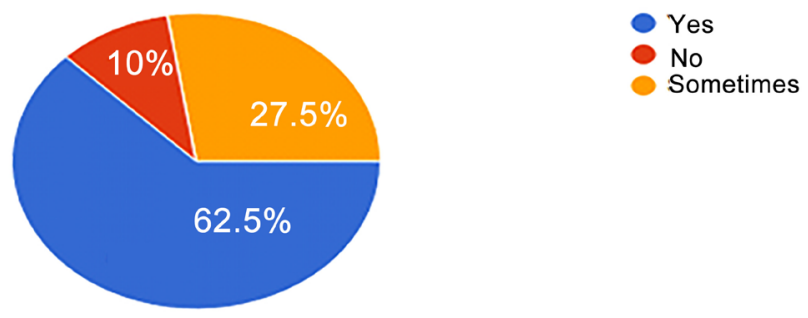

Sometimes

Figure 5. Work overload status.

Do you get enough time for your family after work? (40 reaponses)

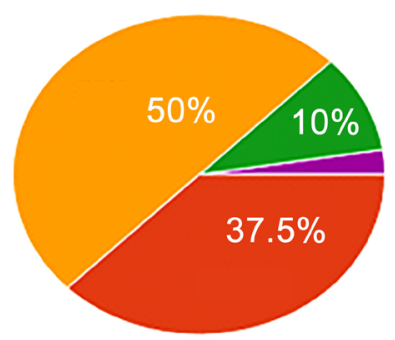

- Never

- Rarely

Sometimes

- Often

- Always

Figure 6. Family time status.

\subsection{Causes}

The analysis dictates that women face problems to maintain balance between work-life mainly because of professional challenges they face every day. These challenges include long working hours (Figure 3), lack of supervisory support 
(Figure 7), work overload, absence of strong policies. As per this study, lack of family support (Figure 6) is an issue but it is not as extensive as professional challenges (Figure 8). Surveys and depth interviews of this study highlighted the fact that working women of today's generation faces more professional challenges than family obstacles.

\section{Does your supervisor support you? (40 reaponses)}

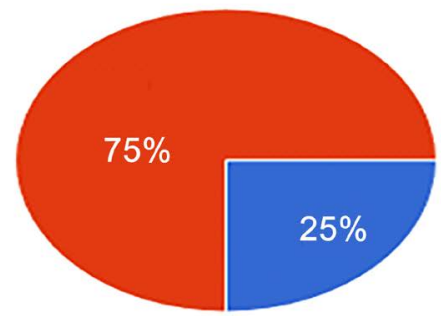

Figure 7. Supervisory support.

Do your colleagus support you? (40 reaponses)

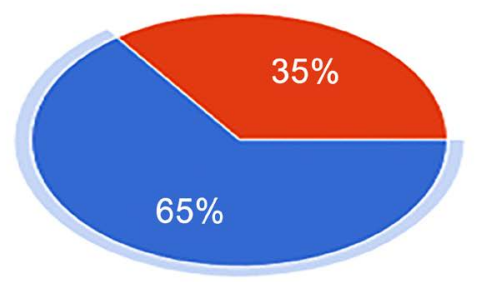

Figure 8. Support from colleagues.

Do you get enough family support for maintaining your professional life? (40 reaponses)

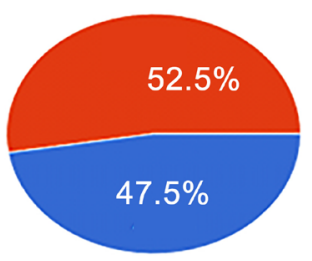

- Yes

Figure 9. Support from family.

Does the organization take initistives to balance work-life of its employees? (40 reaponses)

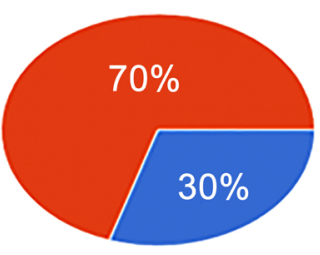

$$
\text { Yes }
$$

No

Figure 10. Organization's initiative to balance work-life. 
For this study the sample size was 40 . Among them $57.5 \%$ are married and $42.5 \%$ are unmarried women working in different private organizations.

In the survey, $40 \%$ of sample has children while $55 \%$ does not have any child.

The next question was asked regarding the daily working hours. $52.5 \%$ responded that they work for $8-8$ hours per day while $35 \%$ work 9 to 10 hours per day. Only $12.5 \%$ work in between $7-8$ hours.

From Figure 4 we can see that $22.5 \%$ were satisfied with their working hour, the majority of the respondents $77.5 \%$ were not satisfied with their working hour.

When asked about the work overload status majority of the respondents $62.5 \%$ responded that they are overloaded with work pressure while only $10 \%$ said they don't feel overload with work at their workplace.

From Figure 6: 50\% said they can sometime manage time for their families, $37.5 \%$ said they can spend time with their families rarely. Only $10 \%$ responded they get enough time to spend with their families.

When asked about the supervisory support $75 \%$ responded negatively that they don't get enough support from their supervisor while $25 \%$ responded they get support from their supervisor

Form Figure 8: 65\% responded that they get support from their colleagues while $35 \%$ responded they are not getting enough support from their colleagues

When asked about the family support, $47.5 \%$ responded positively while $52.5 \%$ said they don't get support from their families.

Figure 10 shows that $70 \%$ said their organizations do not take any initiative to balance between work and life. $30 \%$ said their organization is well aware and have taken initiative to balance between work-life.

From the above Table 1, it is showed that $77.5 \%$ of women are dissatisfied with their working hour. While taking interviews, the respondents claimed that they work for more than 8 hours in regular basis and these long working hours are affecting their personal life. $62.5 \%$ of women feel that they are overloaded with work and always feel the pressure of not fulfilling their work target. Lack of supervisor's support is another vital reason for not being able to make a balance between work and life. 75\% of women stated that their supervisors are not supportive which, is a big issue for them when it comes to balance between work-life. Majority of the respondents are happy with the support they get from their colleagues and from the interview we can say that sufficient support from colleagues work as a relieve system. The rate of family support has been increasing gradually and families are now more supportive than previous time. $47.5 \%$ of women said that they are getting enough family support for maintaining both professional and personal life.

Majority of the respondents complained that their organizations do not take any proper step to keep a balance between work-life. $70 \%$ of the respondents think that organization is incapable of taking any initiative to create a balance between work-life (Table 2). Because of the above mentioned causes, $67.5 \%$ of respondents are facing difficulties to maintain a work-life balance. 
Table 1. Causes of imbalance wok-life.

\begin{tabular}{cccc}
\hline Causes of Imbalance work-life & $\begin{array}{c}\text { Yes } \\
\text { (percentage) }\end{array}$ & $\begin{array}{c}\text { No } \\
\text { (Percentage) }\end{array}$ & $\begin{array}{c}\text { Sometimes } \\
\text { (Percentage) }\end{array}$ \\
\hline Dissatisfaction with working hours & $77.5 \%$ & $22.5 \%$ & $27.5 \%$ \\
Overloaded with work & $62.5 \%$ & $10.0 \%$ & \\
Lack of supervisor's support & $75.0 \%$ & $25.0 \%$ & \\
Sufficient support from colleagues & $65.0 \%$ & $35.0 \%$ & \\
Sufficient family support & $47.5 \%$ & $52.5 \%$ & \\
Capable of balancing work-life & $32.5 \%$ & $67.5 \%$ & \\
Organization's initiative & $30.0 \%$ & $70.0 \%$ & \\
to balance work-life & & & \\
\end{tabular}

Table 2. Percentages of working hour and family time.

\begin{tabular}{cc}
\hline Working Hours & Enough Time for Family \\
\hline $7-8$ hrs: $12.5 \%$ & Rare: $37.5 \%$ \\
$8-9$ hrs: $52.5 \%$ & Sometimes: $50 \%$ \\
$9-10$ hrs: $35 \%$ & Often: $10 \%$ \\
\hline
\end{tabular}

From in-depth interview, we found out that now-a day's women faces more challenges in professional life than personal life. One of the major problem women faces in professional life is the lack of support from their supervisor. This fact has been raised by all of the women in interview. According to the women who have been interviewed, a supportive supervisor can help tremendously in balancing between work-life. One of the interviewee's who work in digital advertising firm said that if her supervisor was a bit supportive and understanding she could have a balanced work-life. Since her supervisor does not communicate with her clearly and does not give her clear direction of work, she faces problems in order to complete her daily tasks which resulted long working hours and create unnecessary mental stress. When the interviewees were asked about how much support they get from their family, 6 of them interviewees positively replied and said they get enough support from their family. One of the interviewee said that her family supports her but she expects a little bit more support from them. Another interviewee said since all of the family members are working, they cannot help her even though they want to. When interviewees were asked how much support they get from their colleagues, everyone responded in a positive manner.

\subsection{Consequences}

This study points out few several psychological and physical problems that women are suffering due to imbalance work-life.

According to this study, Figure 11 highlights that $38.5 \%$ of respondents often feel depressed which hampers both their personal and professional life. $48.7 \%$ of women feel depressed from time to time and $5.1 \%$ of women always feel depressed due to their imbalance work-life. Not only depression but also women 
experience other physical problems such as: Hypertension, Obesity, and Frequent Headache. While $37.5 \%$ of respondents experience hypertension, 30\% of respondent complained that they are facing obesity problems because they sit for more than 8 hours in a day on regular basis at one place and do not move around. From the interview and surveys, we can see the $62.5 \%$ of women experience frequent headache due to excessive workload and long working hours. The work stress that women experience is hampering their personal life as well.

According to the interviewees, because of this imbalance between work-life, they are suffering from depression. Three of the interviewees reported that they have seeing psychiatrist and taking medicine in order to overcome this problem. One of the interviewee said that she is regularly taking professional counseling since she is facing severe depression lately. Not only this, every interviewee stated that because they are focusing too much in professional life, they have become obese because of not doing any physical activities. Not only this but also every interviewees experiencing frequent headache and they have become edgy. Hypertension is another syndrome that has been showed in 4 interviewees' personal life.

\subsection{Solution}

Figures 12-14 have identified some probable solutions to overcome this problem, which will help the women to balance between work-life. One of the major solution has come up from this study is introducing strong policies on work life balance.

According to this study women have suggested that management should include policies such as work from home, flexible working hours and providing

\section{Do you ever feel tired or depressed because of work? (39 reaponses)}
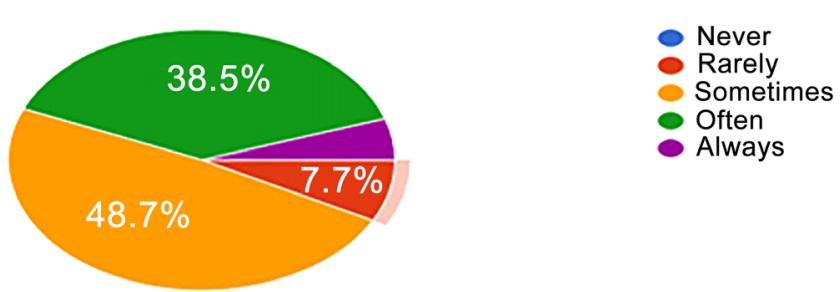

Figure 11. Consequences of imbalance work-life.

Do you suffer form any stress-related disease? (40 responses)

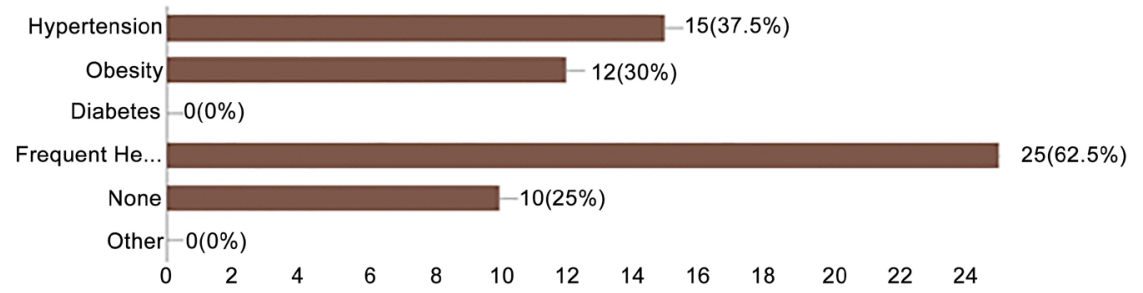

Figure 12. Physical \& Psychological problems due to work-life imbalance. 
day care facility. $40 \%$ of respondents said that management should include work from home facility, which will help them to manage both professional and personal chores. $77.5 \%$ of respondents want flexible working hours. According to this survey, flexible working hours will enable them to work more freely which will ultimately lead to job satisfaction. $55 \%$ of respondents stated that day care facility should be provided by the organization in order to mitigate this problem. As per the survey day care facility will encourage more women to join in the organization which will maintain the gender balance overall.

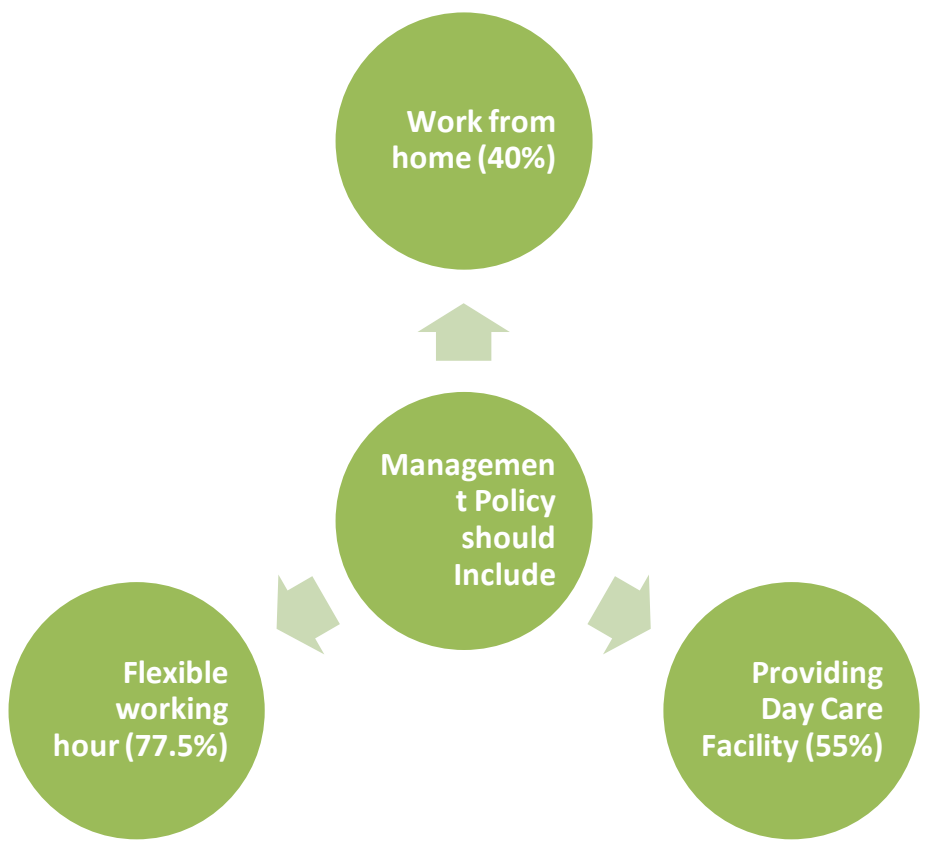

Figure 13. Solutions for maintaining work-life balance.

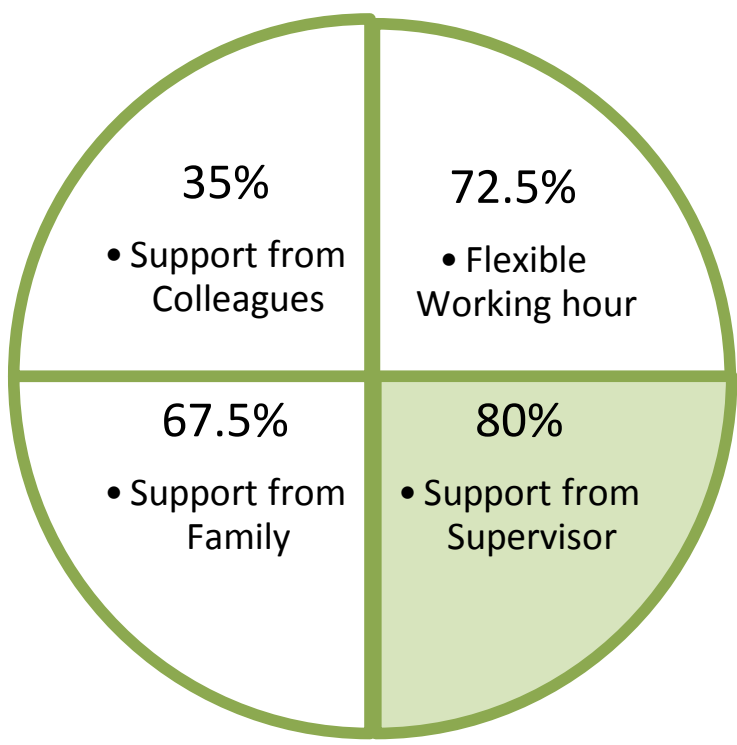

Figure 14. Solutions for maintaining work-life balance. 
In this study, respondents were asked what they want personally from the organization so that balance can be maintained in work-life.

Majority of the respondents stated that a supportive supervisor could change the whole scenario. $80 \%$ of respondent want support from their supervisor in order to maintain work-life balance. $72.5 \%$ of respondents want flexible working hours from their organizations. $67.5 \%$ of respondents believe that support from family can mitigate the imbalance issue from work-life.

Figure 15 indicates $100 \%$ of respondents replied that if employees have good work-life balance, they can contribute to their organizations more effectively which will ultimately lead to success for the organizations.

\subsection{Discussion}

When asked the similar questions in interview, interviewees pointed out the following issues:

Though support from supervisor is needed to maintain balance between work-life, we cannot ignore the support that we get from family. According to the interviewees, family support is also essential in order to maintain a balanced work-life. According to the interviewees who are married, emphasized on the happy married life that a supportive husband plays a vital role in a women's career. One of the interviewees who has been married for 6 years and has a child state that it would have been difficult for her if her husband was not supportive and shared responsibilities which are related to family activities. Both from the interview and from survey, flexible working hour has been found to be useful to most of the working women. Flexible working hour enables them to work freely resulted higher job satisfaction. Interviewees suggested establishing day care center in workplace. Every interviewee supported the fact that formulating strong policy on work-life balance issue can be very helpful in retaining employees that will create a positive atmosphere in the organization.

\section{Conclusion}

Finding from the research indicates that the work-life balance issue has become a significant problem for the working women of Bangladesh. Maintaining a balance between work-life has become relatively difficult because of the unsupportive attitude of supervisors, long working hours and work overload. These causes

Do you think that if employees have good work-life balance the organization will be more effective and successful? (40 reaponses)

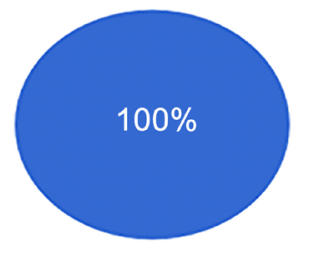

Figure 15. Result of good work-life balance. 
job dissatisfaction and women face obstacles to keep balance between work and life. Work-life balance allows women to maintain both professional and personal life efficiently while imbalance work-life hampers both private and professional life. An imbalanced work-life can hamper one's mental peace and leads to depression which causes several psychological problems. In order to achieve a balanced work-life, this paper focuses on implementing strong policies from organizational perspective. According to this study, support from the organization can help tremendously in maintaining work-life balance. Not only this but also support from supervisor, family and colleagues can positively contribute in this matter. This study has a few limitations. One of the limitations is the sample size. For this paper a small sample size has been selected, therefore the findings can be oversimplified. Further studies can be done in order to investigate this issue more deeply.

\section{References}

[1] Bell, A., Rajendran, D. and Theiler, S. (2012) Job Stress, Wellbeing, Work-Life Balance and Work-Life Conflict among Australian Academics. Electronic Journal of Applied Psychology, 8, 25-37.

[2] Tomazevic, N., Kozjek, T. and Stare, J. (2014) The Consequences of a Work-Family (Im) Balance: From the Point of View of Employers and Employees. International Business Research, 7, 83-100. https://doi.org/10.5539/ibr.v7n8p83

[3] Amstad, F., Meier, L., Fasel, U., Elfering, A. and Semmer, N. (2011) A Meta-Analysis of Work-Family Conflict and Various Outcomes with a Special Emphasis on Cross-Domain versus Matching-Domain Relations. Journal of Occupational Health Psychology, 16, 151-169. https://doi.org/10.1037/a0022170

[4] Allen, T. (2000) Consequences Associated with Work-to-Family Conflict. Journal of Occupational Health Psychology, 5, 278-308.

https://doi.org/10.1037/1076-8998.5.2.278

[5] Hutcheson, P. (2012) Work-Life Balance. IEEE-USA, USA.

[6] Beutell, N. and College, I. (2010) The Causes and Consequences of Work-Family Synergy: An Empirical Study in the United States. International Journal of Management, 27, 650-664.

[7] Nadeem, M. and Abbas, Q. (2009) The Impact of Work Life Conflict on Job Satisfactions of Employees in Pakistan. International Journal of Business and Management, 4, 437-488. https://doi.org/10.5539/ijbm.v4n5p63

[8] Hill, E., Hawkins, A., Ferris, M. and Weitzman, M. (2001) Finding an Extra Day a Week: The Positive Influence of Perceived Job Flexibility on Work and Family Life Balance. Family Relations, 50, 49-58.

https://doi.org/10.1111/j.1741-3729.2001.00049.x 
Submit or recommend next manuscript to SCIRP and we will provide best service for you:

Accepting pre-submission inquiries through Email, Facebook, LinkedIn, Twitter, etc. A wide selection of journals (inclusive of 9 subjects, more than 200 journals)

Providing 24-hour high-quality service

User-friendly online submission system

Fair and swift peer-review system

Efficient typesetting and proofreading procedure

Display of the result of downloads and visits, as well as the number of cited articles Maximum dissemination of your research work

Submit your manuscript at: http://papersubmission.scirp.org/

Or contact jhrss@scirp.org 